\title{
Management Curriculum Through the Semester Credit System (SKS) In the Competency Standards To Improve the Quality of Education
}

\author{
Sasmito Pribadi ${ }^{{ }^{*}}$, Mujamil Qomar ${ }^{2}$, Agus Zaenul Fitri ${ }^{3}$ \\ ${ }^{1}$ Doctoral Student, State Islamic Institute of Tulungagung, Tulungagung, \\ East Java, Indonesia \\ ${ }^{2,3}$ State Islamic Institute of Tulungagung, Tulungagung, East Java, Indonesia \\ ${ }^{*}$ Corresponding Author: \\ Email: mitobadi@gmail.com
}

\begin{abstract}
.
Credit semester system in SMAN 1 Kedungwaru Tulungagung and MAN 1 Trenggalek based on the results of the interview with the head of school/madrasah which states that to provide services to students who have learning speed is high, the policy of the ministry of education that should pay attention to the potential of each student, the school/madrasah already accredited A reserves the right to determine the implementation is better that the package system and the credit system semester, as well as pay attention to the readiness of the school. The purpose of this study was to determine the planning, implementation and supervision of the Semester Credit System (SKS) in the competency standards to improve the quality of education at SMAN 1 Kedungwaru Tulungagung and MAN 1 Trenggalek. This research is useful to add insight, mindset, attitude, and experience as an effort to explore the implementation of the curriculum through the semester credit system in improving the quality of education. The research approach using qualitative methods. The technique of data collection was participant observation, in-depth interviews and documentation. The data analysis technique used is 1) the data analysis of a single case, 2) the analysis of cross-site. The research results show that: the Planning competency standards done with meet the criteria graduation graduation criteria subjects and each semester and education unit in the meeting of the board the teacher set. The implementation of the competency standards do with the criteria for graduation students in accordance with the provisions applicable in the madrasah. Supervision competency standards of graduates conducted on each end of the semester include the presence of students, educators, until the results of the evaluation.
\end{abstract}

Keywords: Curriculum, Semester Credit System (SKS), the Quality of Education

\section{INTRODUCTION}

Quality education will generate resources that will be able to compete with other nations. Quality education is not a stand-alone but it is a unity that is interconnected and related to as a process in a system, when talking about the quality of education it will not be separated from the three elements of education, namely input, process, and graduates. The existence of the graduates of the educational institution is human resources (HR) become the subject and object of development that need to be improved through the path of education in the functions, processes, and activities that lead to the achievement of national education goals (Mulyono, 2013). The success of efforts to increase the quality of education is strongly influenced by the 
quality of human resources involved in it because in the system of education, comfort, quality and professionalism of "the man behind the gun" is the key to the success of the education system. Human resources (HR) as the heart of a system is a major component in the management of education. This suggests that improving the quality of skills and professionalism of the personnel is a necessity in improving the quality of education (Majid, 2012).

Curriculum development in Indonesia is inseparable from the history of the development of education. In the Dutch colonial era until Japan already contained a school for the indigenous people and of course, already there is the curriculum used. But the purpose of education at that time educating human resources that can be used to help the mission of colonialism. So the development of education since the colonial era, the era of the old order and the new order, the reform era to the current era of globalization continues to grow, including in case of changes in the curriculum.Curriculum changes aimed at improving and enhancing the quality of national education. This is done to assess the relevance of the curriculum with the development of the times are constantly changing dynamically. Life in a global era demands a variety of changes in education that are fundamental, among others: changes from the view of life of the local community to the global community, the change of social cohesion into democratic participation, and change from economic growth to human development (Mulyasa, 2013). To achieve the goal of education is required changes in the system of national education through the curriculum, which in itself will bring a variety of changes in each component of the education can be done by evaluating and updating the curriculum of education.

The curriculum is based on the Law Number 20 Year 2003 about National Education System states that curriculum is a set of plans and arrangements regarding the objectives, content and teaching materials as well as the means used to guide the implementation of learning activities to achieve specific educational goals (Muhardi, 2004). To achieve the goal of education is required changes in the system of national education through the curriculum, which in itself will bring a variety of changes in each component of the education of the other. The curriculum is expected to solve the problems of the nation, especially in the field of education to prepare learners through the planning, implementation and evaluation of the education system effectively and efficiently. Therefore, the positive is when the government revitalize the character education in all types and levels of education (Widyaningsih, Riyanto, \& Mudjiarto, 2018). The curriculum has a very important role in education worldwide. With the suitability and the determination of each component in the curriculum of the expected goals and objectives of education can be achieved optimally.

Changes in the curriculum from the curriculum KBK KTSP 2006 to 2013 curriculum is currently an effort in improving the quality of national education after the evaluation of the curriculum in accordance with the needs of learners in Indonesia. 
Curriculum changes done one of them also to improve the quality of education to avoid schools that are concerned with imaging of the school than on the quality of education.

Achieve quality education needed excellent service to the students in accordance with the characteristics of intelligence and talent respectively. To serve learners some particular school has held an accelerated program that later evolved into the independent schools that apply the Semester Credit System (SKS).The implementation of Semester Credit System (SKS) at the level of primary and secondary education in Indonesia today is an innovative efforts to improve the quality of education. Essentially, the SKS is the embodiment of the mandate of Article 12 Paragraph (1) of Law Number 20 year 2003 about National Education System. The article mandates that "Any student at any educational unit shall have the right, among others: (b) obtain educational services in accordance with their talents, interests, and abilities; and (f) complete the educational program in accordance with the individual learning speed and do not deviate from the provisions of the set time limit. The mandate of the article are elaborated further in the Government Regulation No. 13 of 2015 on National Education Standards and Permendikbud No. 21 of 2016 concerning the Standards of the Contents of primary and Secondary education which contains about the Level of Competence and the Competence of the Incident in accordance with the level and the particular type of education. As known that the Standard of the Content is one of the eight National Education Standards (Tjokorda Gde Putra Wirama, Suja, \& Tika, 2019). Content standards set that the burden of learning consists of two kinds, namely: (1) the Package System, and (2) Semester Credit System.

CREDITS organized by organizing learning varied and management of flexible time is done through the provision of units of learning intact any subjects that can be followed by students in accordance with the speed of learning, respectively. Learning is a system which consists of the components of the system instructional i.e. a component of a message, people materials equipment, techniques, and background or environment (Majid, 2014).Although the SKS is already referred to in the Content Standards, but it was not loaded and described in detail because the Content Standards within a set System Package. More of such statements are: "the Burden of learning is regulated to the provisions of this is a load of learning system package on primary and secondary education. The Package system in the Standard Fill is defined as a system of implementation of the program of education that the students are required to attend the entire program of learning and burden of learning that have been defined for each class in accordance with the structure of the curriculum is applicable in the educational unit. Burden of learning any subjects on the Package System is expressed in units of hours learning." The burden of learning with the System Package only gives one possibility, that all students must use the same way to complete the program of study. The implications of this is that learners who are good at will be forced to follow other learners who have the ability and speed of learning standards. Learning system sort of 
it is considered less give the room a democratic for the development of potential learners that include the ability, talent, and interest. Different with the Package System, the burden of learning with the Credits give the possibility to use more varied and flexible according to ability, talent, and interests of learners. Therefore, the application of Credits is expected to accommodate a plurality of potential learners. Through the Credits, students also possible to complete education programs more quickly than the learning period is specified in each educational unit. Credits in the Content Standards is defined as a system of implementation of the program of education that the students determine for themselves the burden of learning and subjects followed each semester in the educational unit. Burden of learning any subjects on a system of semester credit is expressed in semester credit units (credits). The burden of learning a credits include one hour of learning face-to-face, one-hour structured assignments, and one hour of unstructured activities independently." Badan standar Nasional Pendidikan (BSNP) in accordance with the authority stipulated in Government Regulation No. 13 of 2015 on National Education Standards need to compose a "Guide the Implementation of Credits for Secondary School/Madrasah Tsanawiyah (SMP/MTs) and senior high School/Madrasah Aliyah (SMA/MA)".

Learning Model commonly applied in the system package less trigger the creativity of students who have IQ above average. Therefore, the Program Semester Credit System (SKS) is an education services that are relevant to the improvement of the quality of the maximum, so that the talents and intelligence of the students are well developed and the maximum. As the results of a survey of SMAN 1 Kedungwaru Tulungagung and MAN 1 Trenggalek where the implementation of the Credits at the level of upper secondary education is an innovative efforts to improve the quality of education and an education that is equitable. The implementation of semester credit system (SKS) is a service school to the needs of students, in accordance with the potential interests and skills as well as their respective helped students in doing accelerated learning in school. There are three problems in education that must be addressed immediately in Indonesia. He stated that issue refers to the results of the survey Programme for International Student Assessment (PISA) or the Program for International Student Assessment (Sutrisna, 2021). From the survey results of PISA 2018, the average score of Indonesia decreased in the three fields of competence with a decrease in the fields of reading, namely 371 at position 74 . The average reading ability of countries in The Organisation for Economic Co-operation and Development (OECD) had a score of 487. While math skills are on a score of 379 position 73 and the ability of science with a score of 396 in position 71 . The three main problems that must be overcome. The first issue, is the magnitude of the percentage of students achieving low. He is the target number of students achieving low can be pressed up to the range of 15-20 percent in 2030, although Indonesia has managed to increase access to child 15 years of age against the school system but still need to attempt bigger pressing of student achievement of low-in the range of $15-20$ per cent in 2030.SEET The 
second problem is the percentage of students repeating a class that is still high reached 16 percent. According to him, this amount is a lot of 5 percent compared to the average percentage of students repeating a class in OECD countries.

Credit semester system implementation is expected to improve the quality of education in various educational institutions in particular the high school level over the better quality the quality of education, quality of learning and quality of learning outcomes as well as the output of the institution. Quality education is education that can produce graduates who have the basic skills to learn, so that it can follow even become a pioneer in the update and change by way of empowering the sources of educational optimally through teaching and learning, and choice (Chafidz, 1998). The Program credit semester at SMAN 1 Kedungwaru Tulungagung and MAN 1 Trenggalek have a variety of benefits both for the student and the school/madrasah. For schools, a program credit semester system this allows the power of education will multiply the hours of lessons in accordance with the load of the credit system semester every field of study, and can facilitate the acceleration and the period of learning so efficient in the budget. For students, having the ability to learn high can save time, cost and lifespan, so it can focus more on when entering in education next. Students who have high ability and standard each have the advantages of the program semester credit system. The uniqueness of SMAN 1 Kedungwaru Tulungagung criteria for graduation include: complete the entire burden of learning a minimum of 136 hours of the lesson, have the value of all subjects in each semester 1-6, have the attitude of a minimum of either (b), pass school exams with the average value of all subjects 65 (above KBM National), the national examination all subjects tested. While MAN 1 Trenggalek criteria graduation namely the graduation subjects in accordance with the KKM set, graduation each semester can be seen from the results of the report and graduation from the educational unit based on the forum the meeting of the board of teachers.

With a program credit semester system can improve the quality of education can be seen from the achievements obtained from SMAN 1 Kedungwaru Tulungagung, namely the achievement level of the district, national, and even international among the achievements achieved, SMAN 1 Kedungwaru will graduate students who follow a semester credit system (SKS), taken during the six semesters or two years. While in MAN 1 Trenggalek achievements earned that achievement at the district level and national including champion science olympiad, quiz, speech contest and so on. In addition to the above achievements, there are still positive things with the implementation of the credit system semester including MAN 1 Trenggalek be qualified evidenced from the output of MAN 1 Trenggalek that is widely accepted in the universities. Quality education is education that addresses the various challenges and problems that will be faced now and in the future. From here it can be concluded that the quality of education is the ability of institutions and the system of education in empowering the source-a source of education to improve the quality appropriate with 
the hope or goal of education through the educational process that is effective. Quality education is education that can produce quality graduates, namely graduates who have the academic and non-academic to be able to become a pioneer of updates and changes so as to respond to the various challenges and problems that it faces, both in the present or in the future (hope of the nations).

Credits system make the students perceive the curriculum credits with a positive, students will be more actively seeking academic information school, actively ask in class and the presence of competition achievement between students (Nurhidayah, Widodo, \& Desiningrum, 2012). Achievement is defined as the achievements of the school in an effort to simultaneously according to the demands of stakeholders such as students eligible for further study in an institution of learning of high ranking and won a national test scores are high (Supriyanto, Sujinah, \& Robiana, 2020). The presence credits in school students will strive to excel one above each other, competing to grab the interpretation that best, for example to get a high score in order to take subjects as much as possible so that students will more quickly complete the task of learning in school to continue their education to a higher level.

\section{METHODS}

This study uses a Qualitative approach (Moleong, 2013). While the types of research studies multikasus. Source direct data can be collected with the background of the natural (naturalsetting). Analyze and find thoroughly and about the whole planning, implementation and supervision of the Semester Credit System (SKS) in the competency standards to improve the quality of education at SMAN 1 Kedungwaru Tulungagung and MAN 1 Trenggalek. The technique of data collection is as follows: 1) participant Observation (participant observation): Observation is the way in which the researcher to obtain information directly regarding the planning, implementation and supervision of the Semester Credit System (SKS) in the competency standards to improve the quality of education at SMAN 1 Kedungwaru Tulungagung and MAN 1 Trenggalek.

In this observation, the researchers involved with the daily activities of the person being observed or used as a source of research data. 2) in-depth Interviews (indepth interview): an Interview conducted by the researcher to obtain information about the planning, implementation and supervision of the Semester Credit System (SKS) in the competency standards to improve the quality of education at SMAN 1 Kedungwaru Tulungagung and MAN 1 Trenggalek. Interviews were conducted with school principals, and the development of credit semester system in schools.3) Documentation (documentation):the Document is a record of events already past. Documents can be in the form of text, images, or monumental works of the school. Analysis of the data there are three stages that must be done include:(1).Data reduction;(2).Display data;(3). Conclusing drawing(data verification) (Miles, Huberman, \& Saldaña, 2014). 


\section{RESULT AND DISCUSSION}

Planning a Semester Credit System (SKS) in the competency standards improve the quality of education Planning is the phase of the fundamental must be well prepared by the school as a reference implementation of the program, which is aimed at achievement of the set objectives (Budiyanto, Rachim, \& Isyrarini, 2020). Planning a Semester Credit System (SKS) in the competency standards to improve the quality of education is carried out with the provision of students passed must meet the graduation criteria such unresolved burden of learning a minimum of that has been determined, have the value of all subjects, the minimal value of good manners, pass your exam and follow the national exam, which is determined from the results of the meeting of all educators and team credit semester system in the school/madrasah. Permendikbud RI No. 158 of 2014 on the Implementation of the Credit System Semester at the Elementary and Secondary Education article 1, paragraph 2, semester credit System is a form of education that students can determine the amount of load learn to own every semester in accordance talents, abilities and interests. According to the Oemar, SKS is a system of education that wear semester credit units to report the burden of students ' learning and the workload of teachers.

This system can be interpreted as a tribute to the achievements of students in the fields (Hamalik, 1991). Semester credit system allows the implementation of various educational services that are flexible and adapted to the competence, talent, and interests of students. The application of such a system is expected to accommodate the potential of a diverse student that comes down to the learning outcomes more quickly than the time stated by the school (Budiyanto et al., 2020).Competency is the expertise of the minimum mandatory achieved by the students after graduating from education at a certain level of education (Sanjaya, 2009). Competency iaalah that can work on the activities of the industry with its own expertise. Competency is a skill that must be owned learners completed a pass from the school in accordance with existing standards. Based on LAW No. 20 Year 2003 About national Education system in article 35 paragraph (1) which reads the competence of graduates is the qualification of the ability of graduates which includes attitudes and knowledge and skills in accordance with the national standards that exist.SMAN 1 Tulungagung and MAN 1 Trenggalek is to the respective schools in the region that requires students to have good competence after school. In addition, the value of KKM high or exceed the standard, able to stimulate the students to get the value competence above the KKM. This can be evidenced from the results of the attitudes, knowledge and skills of students in report card that no one under the KKM and always on the rise.

Competency standards graduates also according to Permendikbud No.20 of 2016 concerning the Standards of Competence of Graduates, each graduate unit of elementary and secondary education has the competence on three dimensions, namely: the dimensions of the attitude, knowledge dimension, and the dimensions of skills. 
Qualifications skills students diharapa have the skills of thinking and acting which include creative, critical, productive, independent, communicative, and collaborative. Semester Credit system (SKS) is one form of the development of the curriculum implementation is different with the previous program. If the previous program using the Package System, where all the burdens of every student's learning generalized in completing the program of study. Then the System Credits this Semester, students can determine for themselves the burden of learning in accordance with the capabilities, interests and talents of students. The implementation of Semester Credit System (SKS), is expected to bring a change for the better again. Because of the Credits the student is free to choose the burden of their own learning according to the abilities, interests and talents, so that could quickly complete the program of learning more quickly than other students, so as to improve the competence of graduates in the school which includes the attitudes, knowledge and skills of students. Competencies of graduates each year to make the school/madrasah always managed to make the students accepted in favorite State Universities and various schools official.

\section{The implementation of the Semester Credit System (SKS) in the competency standards improve the quality of education}

Implementation as an application of the ideas, concepts, policies, or innovation in a practical actions that impact, either in the form of changes in knowledge, skills and values, and attitudes" (Susilo, 2006). Implementation is a process of the implementation of policies or in the application of a concept to provide a change towards the better. In this case the implementation and adoption is something that has been there to get better results than ever before. This is reinforced by research Dehghani, Pakmehr, \& Jafari (2011) proper management and previous experience has a major role in selecting and assigning competent manager. The implementation of the Semester Credit System (SKS) in the competency standards to improve the quality of education is carried out with the criteria of graduation of students seen from: 1) complete the entire burden of learning a minimum of 136 hours of instruction, 2) have the value of all subjects in each semester, 3) has the value of the attitude of a good minimum, 4) pass the school exam with the average value of all subjects 70 (above KBM National, 5) follow the national exam all subjects tested, 6) have to take the exam in accordance with the provisions applicable in the madrasah.

Based on the findings of the study the implementation of the Semester Credit System (SKS) in the competency standards of graduates already performing well, it could have an effect on the improvement of the competence of graduates, ranging from the value of the attitudes, skills and knowledge. With the Semester Credit System (SKS), students are required so the more active and independent in learning. In addition, it also makes the students to be more motivated to study harder because they can learn according to their speed of learning. Semester Credit system (SKS) this also has an effect on the output of students in accordance with the criteria of competence of graduates. Aside from the value in the report card, from his manner of a good student, 
while the knowledge and skills proven in addition to many State Universities, as well as many who entered the School Official which test his entrance that requires knowledge and skills. It is proved that due to the Semester Credit System (SKS), the competence of graduates increased.

The findings of this study also reinforce the theory Crosby (1979) that the quality is conformance to requirements, namely in accordance with the required or standardized. A product's quality in accordance with the standards or quality criteria that have been determined, the quality standard they include raw materials, production processes, and finished products. Likewise, according to Edward Sallis stated that quality improvement should be implemented consistently in order that the consumer gets the best quality on the procedures and products. This statement confirms that the quality and apply standards that are inherent in the process and the product. Adherence to appropriate activities that meets the procedure and the realization of products that meet the criteria to be completely understood as a basic principle in improving the quality of education (Sallis, 2002).Quality targets should be didefinisakan clearly. Realize SKL (competency standards) who earned the achievements of international competition as the pinnacle of achievement need to be spelled out in the formulation of more specific and described pentahapannya. The school must be good at describing the phasing achievement of the target SKL and the phasing process to achieve the excellence that is adjusted with the resources that the school have. Set the target too high without support adequate resources, can go to school, trapping the citizens of the school into apathy.

\section{The supervision of a Semester Credit System (SKS) in the competency standards improve the quality of education}

The supervision of a Semester Credit System (SKS) in the competency standards to improve the quality of education is carried out at the end of each semester includes the level of attendance of students, educators and education personnel, the implementation of the education unit level curriculum and extracurricular activities, student learning outcomes, evaluation results are reported to interested parties. The results of this study strengthen the theory Siahaan, Rambe, \& Mahidin (2006) that the superintendent of the school/madrasah as a part in the process of achieving quality education, hence the quality of trustees will affect the quality of teachers, quality of teachers will affect the quality of the learning process, quality learning process will produce learners who qualified, and in the end if it all bersinerji will affect the overall quality of education.Madrasah or school is an educational institution that is in the process of work is always faced with the input conditions and the environment are not the same.

In such a situation, then the practice of supervision in the madrasa became a very important thing that supervision is a function of the administration to ensure that activities are carried out in accordance with what has been established or desired 
(Djam'an, 2016). Supervision in the school has a very important role, both carried out by the head of the madrasah or supervisor. Efforts to ensure the quality of education, especially in the achievement of national education standards. Challenges of my education in madrasah/school also emerged with the development of globalization of education that automatically demands the supervisory madrasah to respond quickly to respond to change and to pass it on to madrasah-madrasah proxies. The optimization of the function of Supervisory Madrasah in fostering madrasah-madrasah proxies will really help a madrasah to continue improve the quality, in addition to the monitoring that is done internally by the head of the madrasah. Of course the improvement of the quality of the madrasah is in need of some terms, among others, the development of the capacity and capability of the supervisor madrasah, increasing the capacity of the head of the madrasah, improved facilities madrasah, and the main thing is to increase the professionalism and performance of teachers in providing learning services to students.

\section{CONCLUSION}

Management Curriculum Through the Semester Credit System (SKS) In the Competency Standards To Improve the Quality of Education as follows: Planning the Semester Credit System (SKS) in the competency standards to improve the quality of education is carried out with the meet the graduation criteria such unresolved burden of learning a minimum of that has been determined, have the value of all subjects, the minimal value of good manners, pass your exam and follow the national exam, established from the results of the meeting of all educators and team credit semester system in the school/madrasah.

The implementation of the Semester Credit System (SKS) in the competency standards to improve the quality of education is done with done with the criteria of graduation of students seen from: 1) complete the entire burden of learning a minimum of 136 hours of instruction, 2) have the value of all subjects in each semester, 3) has the value of the attitude of a good minimum, 4) pass the school exam with the average value of all subjects 70 (above KBM National, 5) follow the national exam all subjects tested, 6) have to take the exam in accordance with the provisions applicable in madrasah, then the quality of education can be increased with better. The supervision of a Semester Credit System (SKS) in the competency standards to improve the quality of education is carried out at the end of each semester includes the level of attendance of students, educators and education personnel, the implementation of the education unit level curriculum and extracurricular activities, student learning outcomes, evaluation results are reported to interested parties.

\section{ACKNOWLEDGMENTS}

Based on the results of the research that has been put forward by the researchers, the implications for the practical Management of the Curriculum Through the Semester Credit System (SKS) in Improving the Quality of Education is expected 
to unlock insights and discover the new guidelines for schools that there is an area Tulungagung and Psychology in general in an effort to improve the quality of the school/madrasah through the steps of management: planning, implementation and supervision of the Semester Credit System (SKS) in the competency standards, content standards, process standards and assessment standards.

Program Semester Credit System (SKS) is an education services that are relevant to the improvement of the quality of the maximum, so that the talents and intelligence of the students are well developed and the maximum. implementation of the Credits at the level of upper secondary education is an innovative efforts to improve the quality of education and an education that is equitable. The implementation of semester credit system (SKS) is a service school to the needs of students, in accordance with the potential interests and skills as well as their respective helped students in doing accelerated learning in school. Credit semester system implementation is expected to improve the quality of education in various educational institutions in particular the high school level over the better quality the quality of education, quality of learning and quality of learning outcomes as well as the output of the institution.

\section{REFERENCES}

[1] Budiyanto, Rachim, A. S., \& Isyrarini. (2020). Credit System for Senior High School Student: An Experiment to Meet with the Various Student Learning Pace, Indonesian.

Journal of Curriculum and Educational Technology Studies, IJCETS, 8(1), 13-21.

[2] Chafidz, A. (1998). Sekolah Unggul Konsepsi dan Problematikanya. MPA, (142).

[3] Crosby, P. B. (1979). Quality Is Free. New York: New American Library.

[4] Dehghani, M., Pakmehr, H., \& Jafari, H. (2011). Managerial Challenges of Curriculum Implementation in Higher Education (hal. 2003-2006). Procedia Social and Behavioral Sciences 15 .

[5] Djam'an, S. (2016). Pengawasan dan Penjaminan Mutu Pendidikan. Bandung: Alfabeta.

[6] Hamalik, O. (1991). Manajemen Belajar di Perguruan Tinggi Pendekatan Sistem Kredit Semester (SKS). Oema (Bandung: Sinar Baru.

[7] Majid, A. (2012). Belajar Dan Pembelajaran Pendidikan Agama Islam. Bandung: PT Remaja Rosdakarya.

[8] Majid, A. (2014). Belajar dan Pembelajaran. Bandung: PT RosdaKarya.

[9] Miles, matthew B., Huberman, A. M., \& Saldana, J. (2014). Qualitative Data Analysis. New Delhi: SAGE Publications.

[10] Moleong, L. J. (2013). Metode Penelitian Kualitatif. Bandung: Remaja Rosdakarya.

[11] Muhardi. (2004). Kontribusi Pendidikan dalam meningkatkan Kualitas Bangsa Indonesia. Mimbar, $X X(4)$.

[12] Mulyasa, E. (2013). Pengembangan dan Implementasi Kurikulum 2013. Bandung: PT. Remaja Rosdakarya.

[13] Mulyono. (2013). Strategi Pembelajaran Menuju Efektifitas Pembelajaran di Abad Global. Malang: UIN-Maliki Press.

[14] Nurhidayah, F., Widodo, P. B., \& Desiningrum, D. R. (2012). Relationship Between the http://ijstm.inarah.co.id 
Perception Curriculum Credit Semester System (SKS) With Academic Achievement Motivation in Students Of SMAN 78 Jakarta. Jurnal Psikologi, 1(1).

[15] Sallis, E. (2002). Total Quality Management in Education, Third Edition. Taylor \& Francis e-Library.

[16] Sanjaya, W. (2009). Perencanaan Dan Desain Sistem Pembelajaran. Jakarta: Prenada Media Group.

[17] Siahaan, A., Rambe, A., \& Mahidin. (2006). Manajemen Pengawas Pendidikan. Ciputat: Quantum Teaching.

[18] Supriyanto, E., Sujinah, \& Robiana, P. (2020). The Semester Credit System For Curriculum Design In Indonesian Islamic Schools. Psychology And Education, 57(8).

[19] Susilo, J. (2006). Manajemen Pendidikan. Jakarta: Rineka Cipta.

[20] Sutrisna, N. (2021). Analisis Kemampuan Literasi Sains Peserta Didik Sma Di Kota Sungai Penuh. Jurnal Inovasi Penelitian, 1(12).

[21] Tjokorda Gde Putra Wirama, Suja, I. W., \& Tika, I. N. (2019). Implementasi Sistem Kredit Semester Pada Pembelajaran Kimia di SMAN Bali Mandara. Jurnal Penelitian Pendidikan Kimia: Kajian Hasil Penelitian Pendidikan Kimia, 6(2).

[22] Widyaningsih, R. A., Riyanto, Y., \& Mudjiarto. (2018). Mudjiarto, The Implementation of Curriculum 2013 Using Semester Credit System At Senior High School. Advances in Social Science, Education and Humanities Research, 212. 